\title{
A Human Capital Evaluation of Graduates from the Faculty of Management Sciences Employability Skills in South Africa
}

\author{
Petronella Jonck \\ (PhD Psychology; Hons Industrial Psychology) \\ Deputy Director of Research and Policy Development, Department of Community Safety, Gauteng Government \\ Email: petrojonck@hotmail.com/Petronella.Jonck@Gauteng.gov.za
}

\section{Doi:10.5901/ajis.2014.v3n6p265}

\begin{abstract}
Previous research on employability has underscored the supply side perspective which for the most part focuses on curriculum design and teaching methods. However, ultimately industry is the consumers of graduates produced by higher education. Consequently, the demand side perspective on employability should also be taken into consideration. The objectives of this study were twofold namely evaluating graduates' from Management Sciences current employability skills from the demand side based on a human capital approach as well as to elicit employers' perception on generic skills graduates are lacking. To this end ex post facto research was undertaken by utilizing a questionnaire with a reliability of 0.97 and an inter-item correlation of 0.405340. The sample consisted out of 503 employers from diverse South African business sectors. Statistical analysis indicated that the respondents were less than satisfied with graduates' employability skills. The findings show need for the inclusion of generic business administration skills that specifically emphasise customer service, Excel training and financial management.
\end{abstract}

Keywords: Human capital theory, employability, critical cross field outcomes, graduate attributes, employers.

\section{Introduction}

Global trends such as increasing vocationalism, mass education, marketisation and increased competitiveness between universities, have both locally and abroad, led to apprehension with regard to the employability of graduates (Green, Hammer \& Star, 2009). Higher education is consequently under increasing pressure to validate its expenditure on the development of graduates' skills and to show its relevance in the knowledge economy (Backhouse, 2010; Campbell, 2010). The purpose of contemporary tertiary education is to ensure graduates gain a comprehensive education that increase the likelihood of gaining and sustaining employment, with benefits to all stakeholders including the economy (Omar, Manaf, Mohd, Kassim \& Aziz, 2012). Thus the expectations are for higher education to engage proactively with the skills needs of the economy thus business and industry coupled with addressing imperative public constraints referring to governmental expectations.

Business and industry have both nationally and internationally voiced concern over the quality of graduates produced by higher education institutions. In the United Kingdom, one-fifth of reported vacancies could not be filled due to lack of skills, as is the case in Malaysia where 70 percent of graduates were unemployed within six months of graduation (Omar et al., 2012). In India 25\% of graduates were perceived as 'employable' and in China only 10\% (Gamble, Patrick \& Peach, 2010). Locally, it is estimated that there are nearly 600000 unemployed university graduates, while 829800 vacancies remained vacant due to skills shortages (Sharp, 2013). The graduate unemployment rate has increased by an estimated 50\% between 1995 and 2005, which makes it the fastest growing unemployment rate in South Africa (Development Policy Research Unit 2007).

A growing body of research focus on graduate attributes or generic skills in relation with employability (Cummings, 2010; Nair, Patil \& Mertova, 2009; Selvadurai, Choy \& Maros, 2012). However, most research conducted on employability focus on the supply side perspective. Limited research on employability from the demand side has been conducted as can be seen from the following discussion. Bezuidenhout (2011) found that the concept of employability remains vague and in line with the before mentioned statement a lack of empirical justification was indicated. In another study by Bath, Smith, Stein and Swann (2004), university lecturers at an Australian institution who were responsible for implementing graduate attributes in their curriculum, were used as a case study. Beukes (2010) conducted a study regarding employability and emotional intelligence of learners within the school-to-work transitional phase. Both studies focused on 
student's evaluation of their development of graduate attributes. Chapman (2004) developed a Graduate Attribute Guide based on exampled from lecturers for use at the University of New England. No mention is made of research from the employer's perspective, to ascertain whether the attributes were relevant to employability. In a South African study Parker and Griesel (2009) conducted research based on a sample consisting out of 99 private sector employers to determine graduate employability skills in the Johannesburg area. The sample size and the fact that only private sector employers were included while South Africa can be seen as a mixed economy (Mohr, 2012) negatively influence the validity of the findings.

In light of the lack of empirical research from the demand side as evident from the previous discussion the scope of this paper is to evaluate graduates' current employability skills by 503 private and public sector employers within the Free State region of South Africa, specifically the Mangaung area, focussing on both the knowledge and execution aspect of employability. Secondary objectives subsume to elicit employers' perception on generic skills graduates are lacking as well as to determine the biographical determinants that might influence employer's evaluation of employability skills.

For the sake of clarity York and Knight (2006) described employability as a concept that subsume four broad interrelated components namely: skilful practices (communication, management of time, self and resources); specialization in a field of knowledge (academic skills); efficacious beliefs about personal identity and self-worth; and meta-cognition (self awareness and the capability to reflect on actions). Omar et al. (2012) suggest that from the employers' perspective employability refers to 'work readiness' subsuming skills, knowledge attitudes and commercial understanding that will enable graduates to add value to the achievement of organizational objectives after commencement of duties. Thus graduates should not only have knowledge of subject matter but also be able to execute what they have gained in the education process (Selvadurai et al., 2012) incorporating the skills mentioned by York and Knight (2006).

\section{Theoretical Framework}

The theoretical debate on employability centres on two theories namely human development or capabilities theory and human capital theory. Human development or capabilities focus on a plurality of values including but not limited to knowledge generation, professional preparation, cultural knowledge and enlightenment of the public sphere (McLean, Abbas \& Ashwin, 2012). Providing a complex framework, particularly adequate taking into consideration heterogeneity amongst personal factors, context and circumstances in higher education that contribute to vulnerability and marginalization (Chiappero-Martinetti \& Sabadash, 2012). The human development or capabilities theory look at employability of graduates from the supply side thus a higher education perspective. On the other hand the human capital theory emphasises education as a primary economic enabler and essential for participation in the global economy (Bridgstock, 2009). Labour is seen as a factor of production from an employer's perspective, while the term human capital is used to refer to the quality of labour, thus the skills, knowledge and health of employees (Mohr \& Seymore, 2012). When evaluating the employability of graduates from the demand side thus an employer's perspective the skills and knowledge of employed graduates are being evaluated emphasizing a human capital approach to graduate employability skills.

Due to its applicability the human capital theory was used as theoretical paradigm for this paper. More specifically an income-based human capital theory approach was utilized which emphasize the value of expected returns of human capital in terms of the output it can generate (Chiappero-Martinetti \& Sabadash, 2012). This may include increased employability, decreased unemployment, increasing the income-based gross domestic product (tax, wages and salaries), as well as the knowledge and skill endowment of the country. The aforementioned contention is more applicable on developing countries, such as South Africa, since the formation of skills is deemed a top priority (Yabuuchi \& Chaudhuri, 2009). This might not be the case in developed countries. To address unemployment, skills shortages and poverty focus needs to shift from the development of graduates to enhancing the employability of graduates. This is in accordance with The Department of Higher Education and Trainings' mission and vision (RSA DHET, 2011). The promotion of employability and sustainable livelihoods has been identified as areas of importance by the Department of Higher Education and Training in their operational plans for the 2011/2012 financial year (RSA DHET, 2011: 4).

Based on the human capital theory, business and industry is the primary consumers of graduates produced by higher education. In order to remain relevant higher education must adjust curricula to meet the requirements of an everchanging employer market (Wessels \& Jacobs, 2010). As such employers have expressed a need for well rounded graduates who are aware of the labour market and business practices. To this end, it is advocated that graduates should possess transferable skills, especially in relation to communication, human relations and problem solving. To summarize graduates should be competent and not just highly specialised in a narrow academic field of study (Cummings, 2010). 
For higher education to develop a curriculum that underscores employability skills as defined by York and Knight (2006) business and industry should evaluate said competencies, coupled with identifying additional skills that is currently not included in curriculum.

The development of a curriculum that focuses on employability involves sequentially the following steps: needs analysis (referring to the evaluation and identification of graduate attributes and critical cross field outcomes), the determination of teaching methods and the verification of assessment methods which ultimately culminates in programme evaluation. This paper focuses on the first step namely needs analysis which subsumes the evaluation and identification of graduate attributes and critical cross field outcomes of graduates by employers.

Needs analysis is conducted to evaluate current employability skills and to identify deficiencies in current curriculum or to anticipate deficiencies based on expected changes in educational requirements (Hauer \& Quill, 2011). Graduate attributes are the capabilities a higher education institution agrees its students would, best case scenario, develop during their time at the institution (Bridgstock, 2009). Thus, what do graduates need to know to be competent at their chosen profession? Discipline specific and generic skills are the two broad categories of graduate skills. Generic skills subsume terms such as 'key skills', 'generic attributes', 'basic skills', 'key competences', 'transferable skills', 'employability skills', 'soft skills', and graduate attributes'(Beyer, Wilkinson \& Friedrich-Nel, 2010; Du Preez \& Fossey, 2012). Higher education is increasingly focused on the development of generic capabilities despite ongoing debates about the concept and development of such capabilities (McNeil, Scicluna, Boyle, Grimm, Gibson \& Jones, 2011). The term graduate attributes is intended to embrace a broad range of generic personal and professional qualities, skills and dispositions, coupled with the ability to understand discipline related knowledge (Thompson, Treleaven, Kamvounias, Beem \& Hill, 2008). Critical cross field outcomes are the basic generic outcomes, which underscores all teaching and learning and which all students need to achieve at every individual level of development (De Jager 2004). Thus, what should the graduate be able to do?

\section{Methodology}

The objectives of the research study were to ascertain how employers in the central region of the Free State, in South Africa evaluate graduates' employability skills as well as to elicit employers' perception on generic skills and or critical cross field outcomes graduates are lacking. To achieve this aim the following research design was incorporated.

\subsection{Research design}

The research design can be classified as a cross-sectional descriptive quantitative research design. The main objective of a descriptive study is to describe a population phenomenon as accurately as possible at a specific point in time (Salkind, 2011). Based on the time-line the research design can be classified as a cross-sectional design, as it is founded on data gathered by means of the administering of a questionnaire simultaneously, without repeat measures (Du Plessis \& Barkhuizen, 2012). A characteristic of the research design under discussion is that it is an Ex Post Facto design. In non-experimental research, the independent variables are not manipulated to examine their influence on the dependent variables. Thus, the respondents belonged to the different biographical variables prior to the commencement of the study.

\subsection{Data gathering}

Students from a Research Methodology class in the Faculty of Management Sciences at a higher education institution were utilized as fieldworkers in the data gathering phase. One of the critical cross field outcomes currently embedded in all higher education curriculum is research skills which refers to the ability to collect, analyse, organise and disseminate information. This research study was conducted to educate students in data gathering and provide them with the opportunity to integrate knowledge and practice. The questionnaire and consent forms were posted on Black Board and each student had to go to five organisations to complete a questionnaire. In order to ensure the trustworthiness of this process, each questionnaire had to be stamped by the organisation in question, although the respondents remained anonymous.

\subsection{Population and sample}

The population for this investigation includes employers in the central Free 
State region of South Africa, specifically the Mangaung area which constitutes the capital city of the Free State region. The sample consisted out of $503(\mathrm{~N}=503)$ respondents from a Management Sciences perspective. Although 590 questionnaires were collected only 503 were included in the final sample due to incompleteness or lack of consent. The respondents consisted out of 100 human resource managers, 42 heads of departments, 162 supervisors, 116 line managers, 24 sole proprietors and 3 respondents from executive management. The designation of respondents is important ascribed to the fact that the article focuses on the employer's perspective and not general staff. Two hundred and fifty respondents were from the public sector and 253 from the private sector. Sub-divisions within the private sector were finance and banking, construction, logistics and transportation, hospitality, service delivery as well as diverse sectors. A complete description of the demographic composition is discussed in the following section.

\subsection{Measuring instrument}

The measuring instrument used in the study was based on an employability skills model developed by De Jager (2004) which yielded a reliability of 0.96 as measured by Cronbach Alpha and an inter-item correlation of 0.405340 . The questionnaire comprised of three sections namely Section A which captured respondents biographical information, followed by Section B that measured critical cross field outcomes (CCFO's) and lastly, Section C which focused on graduate attributes. The seven critical cross field outcomes that were measured included (De Jager, 2004):

- Problem-solving referring to the ability to identify and solve problems, demonstrating that responsible decisions have been made, using critical and creative thinking.

- Teamwork skills which provides and indication of graduates' capability to work effectively with co-workers as a team member on various levels of complexity including but not limited to a team, group, organizations and community.

- Self-responsibility referring to the capacity to organize and manage self and activities responsibly and effectively.

- Research skills including the ability to collect, analyze, organize and critically evaluate information.

- Communication subsuming communicating effectively by using visual, mathematical and or language skills in various modes including oral and or written presentations.

- Technological and environmental literacy which focus on utilizing science and technology effectively and critically, indicative of a sense of responsibility towards the environment and the well being of others.

- Lastly, the development of macro vision skills underscoring demonstrating an understanding of the world as a set of related systems by taking cognizance of the fact that problem-solving contexts do not exist in isolation.

Graduate attributes were sub-divided to include several competencies and focused in particular on job seeking skills, academic skills, personal and career management, interpersonal skills, work ethics and computer literacy (De Jager, 2004). Questions included evaluating graduates ability to compile professional curriculum vitae, apply theoretical knowledge in work-related situations, presenting information in different formats, demonstrating effective time and stress management, self confidence, discipline, assertiveness, awareness of ethical responsibility as well as overall computer literacy.

Both critical cross field outcomes and graduate attributes (Section B and C) were measured on a 4-point Likertscale where one represents either Total Dissatisfaction (Section B) or Total Disagreement (Section C) and four Satisfied (Section B) or Full Agreement (Section C). The questionnaire also included an open-ended question in order to elicit employers' perceptions on generic skills graduate are lacking by means of discourse and narratives. The inclusion of the open-ended question was aimed at creating a holistic understanding of the subject under discussion. The rational for the use of the questionnaire stems from the inclusion of critical cross field outcomes and graduate attributes as well as the psychometric qualities of the model. A questionnaire used in a similar study by Parker and Griesel (2009) focused only on graduate attributes and didn't include critical cross field outcomes prescribed by the Department of Higher Education in South Africa. Since the previously mentioned study was a pilot study the psychometric qualities of the questionnaire are unknown. In the current study acceptable Cronbach Alpha measures were indicated for both sections ranging from 0.86 for Section B, to 0.97 for Section C and 0.97 for the Total Scale. Additionally, employability skills in the current study was underpinned by the definition of York and Knight (2006) which described employability as a concept that subsume four broad inter-related components namely: skilful practices (communication, management of time, self and resources); specialization in a field of knowledge (academic skills); efficacious beliefs about personal identity and self-worth; and meta-cognition (self awareness and the capability to reflect on actions). All of the above are included in the measuring instrument that was utilized. 


\subsection{Ethical considerations}

Prescribed ethical guidelines (May 2011) were integrated by means of a letter of consent that had to be signed by each respondent. The letter of consent specified that participation was voluntary. Participants were assured of anonymity and associated confidentiality. Respondents were informed of the aim, purpose and outcome of the research project and no physical or psychological harm were imposed on respondents as result of participation.

\subsection{Data analysis}

Statistical analysis was carried out by means of descriptive statistical analysis such as frequencies, percentages, median, mean and standard deviation. Since categorical data lent itself towards a skew kurtosis the use of a median in conjunction with the mean provides a better reflection of the data. Inferential statistical analysis was done by using the Kruskal-Wallis test and Chi-square to determine the significant differences between the construct and the biographical variables. The reliability of the different sections of the questionnaire was determined by means of Cronbach's Alpha coefficient. The open-ended question was analysed using discourse analysis.

\section{Results and Findings}

To contextualize participants' responses, Table 1 provides a description of the biographical data gathered from respondents.

Table 1: Biographical profile of the respondents

\begin{tabular}{|l|l|c|c|c|}
\hline \multicolumn{1}{|c|}{ Variable } & Level of the variable & Frequency & $\%$ & Cumulative \% \\
\hline Position & HR Manager/Officer & 100 & 19.88 & 19.88 \\
\cline { 2 - 5 } & Branch manager & 56 & 11.13 & 31.01 \\
\cline { 2 - 5 } & Head of department & 42 & 8.35 & 39.36 \\
\cline { 2 - 5 } & Supervisor & 162 & 32.21 & 71.57 \\
\cline { 2 - 5 } & Line manager & 116 & 23.06 & 94.63 \\
\cline { 2 - 5 } & Sole proprietor & 24 & 4.77 & 99.40 \\
\cline { 2 - 5 } & Executive management & 3 & 0.60 & 100 \\
\hline \multirow{5}{*}{ Age } & $20-29$ years & 71 & 14.12 & 14.12 \\
\cline { 2 - 5 } & $30-39$ years & 231 & 45.92 & 60.04 \\
\cline { 2 - 5 } & $40-49$ years & 164 & 32.60 & 92.64 \\
\cline { 2 - 5 } & $50-59$ years & 29 & 5.77 & 98.41 \\
\cline { 2 - 5 } & 60+ years & 1.59 & 1.59 & 100 \\
\hline \multirow{5}{*}{ Gender } & Male & 290 & 57.65 & 57.65 \\
\cline { 2 - 5 } & Female & 38 & 72.35 & 100 \\
\hline Academic qualification & Grade 12 & 283 & 56.26 & 63.82 \\
\cline { 2 - 5 } & Diploma/degree & 128 & 25.45 & 89.26 \\
\cline { 2 - 5 } & Honours' degree & 47 & 9.34 & 98.61 \\
\cline { 2 - 5 } & Masters degree & 7 & 1.39 & 100 \\
\cline { 2 - 5 } & Doctoral degree & & & 7.55 \\
\hline
\end{tabular}

As evident from Table 1 above the sample consisted out of 162 (32\%) supervisors, $116(23 \%)$ line managers, 100 (20\%) human resources practitioners, 56 (11\%) branch managers, 42 (8\%) head of departments, $24(5 \%)$ sole proprietors and 3 $(1 \%)$ respondents from executive management. The age distribution of the respondents indicated that $71(14.12 \%)$ were between the ages of 20-29 years, the majority ( $\mathrm{N}=231 ; 45.92 \%)$ between 30-39 years, $164(32.60 \%)$ respondents were between 40-49 years, and 29 (5.77\%) between 50-59 years. Only 8 (1.59\%) respondents were 60 years and older ascribed to the fact that the retirement age is between 60 and 65 years. The sample could be divided into 290 (57.65\%) male and $213(42.35 \%)$ female respondents. With reference to academic qualification the majority of the respondents ( $N$ $=283 ; 56.26 \%)$ were in possession of a diploma or bachelors degree, 128 (25.45\%) held an honours' degree, 47 (9.34\%) a masters' degree, 38 (7.55\%) respondents had a grade 12 diploma and 7 (1.39\%) respondents a doctoral degree.

In order to determine employers' evaluation of graduates' employability skills the results for the measures of central 
tendency are tabulated in Table 2. Take note due to the categorical nature of the variables the median was used in conjunction with the mean. In each case the median represent the 50\% mark (Salkind, 2012). According to Table 2 below respondents was less than satisfied with the critical cross field outcomes (CCFO's) currently embedded in higher education curriculum. Four out of the 7 CCFO's were scored under 50\% including problem-solving skills, research skills, technological and environmental literacy and the development of macro vision skills. Respondents were least satisfied with the development of macro vision skills, which refers to demonstrating an understanding of the world as a set of related systems by recognizing that problem-solving context do not exist in isolation. This was followed by research and problem-solving skills and lastly technological and environmental literacy. Respondents were most satisfied with graduates' ability to work effectively with colleagues. Respondents were reasonably satisfied with the graduate attributes. Only two graduate attributes had a mean score of less than 50\%. Respondents were least satisfied with graduates' academic skills followed by work ethics. With regard to the first mentioned the assimilation and presenting of information in different formats represented graduate attributes respondents were least satisfied with. This was closely followed by the application of theoretical knowledge in work-related situations as well as the re-contextualization of information in various modes. With reference to work ethics respondents indicated the least satisfaction with graduates' punctuality and awareness of ethical responsibility. Respondents were most satisfied with graduates' computer literacy. Despite the latter it was indicated by the written responses of respondents that advance computer skills were lacking.

Table 2: Measured for central tendency for the critical cross field outcomes (CCFO's) and graduate attributes (GA)

\begin{tabular}{|c|l|c|c|c|c|c|}
\hline Variable & Level of the variable & Lower quartile & Upper quartile & Median & $\overline{\boldsymbol{X}}$ & Std \\
\hline \multirow{5}{*}{ CCFO's } & Problem-Solving skills & 2 & 3 & 3 & 2.96 & 0.75 \\
\cline { 2 - 6 } & Teamwork skills & 3 & 4 & 3 & 3.22 & 0.74 \\
\cline { 2 - 6 } & Self-responsibility & 2 & 4 & 3 & 3.01 & 0.81 \\
\cline { 2 - 6 } & Research skills & 2 & 4 & 3 & 2.92 & 0.86 \\
\cline { 2 - 6 } & Communication skills & 3 & 4 & 3 & 3.14 & 0.76 \\
\cline { 2 - 6 } & Technological \& environmental literacy & 2 & 4 & 3 & 2.98 & 0.81 \\
\cline { 2 - 6 } & Macro vision skills & 2 & 3 & 3 & 2.73 & 0.81 \\
\hline \multirow{5}{*}{ GA's } & Job seeking skills & 2.67 & 3.50 & 3 & 3.08 & 0.56 \\
\cline { 2 - 7 } & Academic skills & 2.63 & 3.25 & 3 & 2.95 & 0.53 \\
\cline { 2 - 7 } & Personal/career management & 2.64 & 3.27 & 2.82 & 2.93 & 0.52 \\
\cline { 2 - 7 } & Interpersonal skills & 2.60 & 3.40 & 3 & 3.03 & 0.56 \\
\cline { 2 - 7 } & Work ethics & 2.60 & 3.40 & 3 & 2.99 & 0.64 \\
\cline { 2 - 7 } & Computer literacy & 3 & 4 & 3 & 3.32 & 0.97 \\
\hline
\end{tabular}

In order to determine the secondary objective being the influence of the biographical variables on the two dependent variables (critical cross field outcomes and graduate attributes) results for the comparisons are reported in Table 3 and 4 , below.

Table 3: Kruskal-Wallis Test results for both dependent variables with reference to position and age

\begin{tabular}{|c|c|c|c|c|c|}
\hline \multicolumn{2}{|c|}{ Variables } & Level of the variable & Chi-square & DF & $p$-value \\
\hline \multirow{13}{*}{ Position } & \multirow{7}{*}{ CCFO } & Problem-solving skills & 4.3334 & 6 & 0.6317 \\
\hline & & Teamwork skills & 2.8300 & 6 & 0.8299 \\
\hline & & Self-responsibility skills & 12.8766 & 6 & $0.0450 *$ \\
\hline & & Research skills & 6.1312 & 6 & 0.5271 \\
\hline & & Communication skills & 3.6724 & 6 & 0.7209 \\
\hline & & Technological \& environmental Skills & 5.0721 & 6 & 0.5346 \\
\hline & & Macro vision skills & 10.5537 & 6 & 0.1032 \\
\hline & \multirow{6}{*}{ GA } & Job seeking skills & 9.5317 & 6 & 0.1458 \\
\hline & & Academic skills & 10.3432 & 6 & 0.1109 \\
\hline & & Personal/career management & 16.2203 & 6 & $0.0126^{*}$ \\
\hline & & Interpersonal skills & 13.6626 & 6 & $0.0336^{*}$ \\
\hline & & Work ethics & 17.7374 & 6 & $0.0069^{* \star}$ \\
\hline & & Computer literacy & 6.9721 & 6 & 0.3234 \\
\hline Age & CCFO & Problem-solving skills & 8.7493 & 4 & 0.0677 \\
\hline
\end{tabular}




\begin{tabular}{|c|c|c|c|c|}
\hline Variables & Level of the variable & Chi-square & DF & p-value \\
\hline & Teamwork skills & 9.2195 & 4 & 0.0558 \\
\hline & Self-responsibility skills & 4.2535 & 4 & 0.3728 \\
\hline & Research skills & 7.8718 & 4 & 0.0964 \\
\hline & Communication skills & 4.0413 & 4 & 0.4004 \\
\hline & Technological \& Environmental skills & 12.4146 & 4 & $0.0145^{\star}$ \\
\hline & Macro vision skills & 5.3335 & 4 & 0.2548 \\
\hline & Job seeking skills & 5.5855 & 4 & 0.2323 \\
\hline & Academic skills & 5.8848 & 4 & 0.2079 \\
\hline & Personal/career management & 9.0368 & 4 & 0.0602 \\
\hline$G A$ & Interpersonal skills & 10.7041 & 4 & $0.0301^{*}$ \\
\hline & Work ethics & 8.9041 & 4 & 0.0635 \\
\hline & Computer literacy & 4.7477 & 4 & 0.3142 \\
\hline
\end{tabular}

A statistical significant difference between the critical cross field outcomes and position is indicated by Table 3 with reference to self-responsibility skills, which are defined as the ability of graduates to organize and manage themselves and their activities responsibly and effectively. Similarly, statistical significant differences with regard to personal and career management skills as well as interpersonal skills with reference to graduate attributes were indicated. A highly statistical significance on the $99^{\text {th }}$ percentile was brought to light for work ethics. A statistical significant difference with reference to the different age groups and critical cross field outcomes was indicated for technological and environmental literacy. In addition a statistical significant difference with regard to interpersonal skills with specific reference to graduate attributes and age was indicated.

The Kruskal-Wallis Test results for gender and the critical cross field outcomes pointed out a statistical significant difference for self-responsibility skills on the $95^{\text {th }}$ percentile according to Table 4 below.

Table 4: Kruskal-Wallis Test results for both dependent variables with reference to gender and academic qualification

\begin{tabular}{|c|c|c|c|c|c|}
\hline \multicolumn{2}{|c|}{ Variables } & Level of the variable & Chi-square & DF & p-value \\
\hline \multirow{13}{*}{ Gender } & \multirow{7}{*}{ CCFO } & Problem-solving skills & 0.0021 & 1 & 0.9636 \\
\hline & & Teamwork skills & 0.0614 & 1 & 0.8043 \\
\hline & & Self-responsibility skills & 3.9957 & 1 & $0.0456^{*}$ \\
\hline & & Research skills & 2.7084 & 1 & 0.0998 \\
\hline & & Communication skills & 3.0569 & 1 & 0.0804 \\
\hline & & Technological \& environmental Skills & 3.1790 & 1 & 0.0746 \\
\hline & & Macro vision skills & 0.1262 & 1 & 0.7224 \\
\hline & \multirow{6}{*}{ GA } & Job seeking skills & 1.0968 & 1 & 0.2950 \\
\hline & & Academic skills & 0.0071 & 1 & 0.9330 \\
\hline & & Personal/career management & 0.6998 & 1 & 0.4028 \\
\hline & & Interpersonal skills & 0.0020 & 1 & 0.9645 \\
\hline & & Work ethics & 0.5066 & 1 & 0.4766 \\
\hline & & Computer literacy & 0.4946 & 1 & 0.4819 \\
\hline \multirow{13}{*}{$\begin{array}{c}\text { Academic } \\
\text { Qualification }\end{array}$} & \multirow{7}{*}{ CCFO } & Problem-solving skills & 8.0166 & 4 & 0.0910 \\
\hline & & Teamwork skills & 16.2804 & 4 & $0.0027^{\star *}$ \\
\hline & & Self-responsibility skills & 4.6447 & 4 & 0.3257 \\
\hline & & Research skills & 21.1574 & 4 & $0.0003^{\star \star}$ \\
\hline & & Communication skills & 11.2170 & 4 & $0.0242^{\star}$ \\
\hline & & Technological \& Environmental skills & 21.5412 & 4 & $0.0002^{\star \star}$ \\
\hline & & Macro vision skills & 24.9339 & 4 & $<0.0001^{\star \star}$ \\
\hline & \multirow{6}{*}{ GA } & Job seeking skills & 21.1059 & 4 & $0.0003^{\star *}$ \\
\hline & & Academic skills & 25.1232 & 4 & $<0.0001^{\star \star}$ \\
\hline & & Personal/career management & 22.2273 & 4 & $0.0002^{* *}$ \\
\hline & & Interpersonal skills & 15.9359 & 4 & $0.0031^{\star *}$ \\
\hline & & Work ethics & 8.0274 & 4 & 0.0908 \\
\hline & & Computer literacy & 5.5677 & 4 & 0.2338 \\
\hline
\end{tabular}

${ }^{*} p \leq 0.05 ;{ }^{*} p \leq 0.01$ 
There were no statistical significant differences noted for gender and graduate attributes. Various statistical significant differences were indicated for academic qualification and the critical cross field outcomes. These include communication skills on the $95^{\text {th }}$ percentile, teamwork skills on the $99^{\text {th }}$ percentile, research skills on the $99^{\text {th }}$ percentile, technological and environmental literacy on the $99^{\text {th }}$ percentile, and developing macro vision skills on the $99^{\text {th }}$ percentile. Similar results were evident for all the graduate attributes with the exception of work ethics and computer literacy. Inferential statistical analysis for sector yielded no statistical significant differences with regard to both critical cross field outcomes and graduate attributes.

\subsection{Analysis of the open-ended question}

The open-ended question intended to elicit employers' perception on generic skills graduates are lacking that were not included in the questionnaire. The question was completed by 92 respondents. Some of the additional skills required by industry included but are not limited to:

- Emotional intelligence referring to adaptability, resilience, handling own and others' emotional state, making mistakes and learning from them as well as conflict management and resolution.

- Financial management and skills also subsuming asset management.

- Client service and networking.

- Willingness to start at the bottom and work their way up the ladder.

- Creativity and innovation for example thinking outside the box.

- Cultural intelligence

- Respect for authority, professionalism and the ability to work with sensitive information.

- Advanced computer training including excel and pastel training.

\section{Discussion and Recommendations}

The primary aim of the study was to determine how employers in the Mangaung area in South Africa evaluate graduates' employability skills. The empirical research findings concluded that employers were less than satisfied with the critical cross field outcomes that are currently embedded or ought to be embedded in higher education curricula as stipulated by the national governing body, SAQA (South Africa Qualification Authority). The critical cross field outcome respondent were least satisfied with subsumed problem-solving skills, research skills, technological and environmental literacy and the development of macro vision skills. The before mentioned results underscore research results by Parker and Griesel (2009) which indicated that there were discrepancies between industry expectations, and the outcomes of higher education which are referred to as critical cross field outcomes. Discrepancies centred on task-directed engagement and application of knowledge. This is in spite of research results indicating that employers appreciated the conceptual foundation, knowledge and intellectual approach to tasks which is a result of higher education (Parker \& Griesel, 2009).

In further support of the before mentioned findings the graduate attributes employers were least satisfied with were academic skills and work ethics. With reference to academic skills the assimilation and presenting of information in different formats represented graduate attributes respondents were least satisfied with. This was closely followed by the application of theoretical knowledge in work-related circumstances as well as the re-contextualization of information in various modes. In essence, task-directed engagement and application of knowledge as indicated by Parker and Griesel (2009). These results underline those of Gokuladas (2011) which found that academic skills coupled with communication skills enhanced the employability of graduates. Additionally, a study by Nair et al. (2009) found that employers indicated problem-solving skills, the ability to develop new or innovative ideas to mention a few were essential attributes of employability.

The independent variable that had the most statistically significant influence on the dependent variable was academic qualification. Thus the favourable or unfavourable evaluation of graduates' employability skills was largely determined by the qualification of the employer. Various additional skills were identified by respondents the most mentioned being emotional intelligence, financial management, advance computer training and client service. This finding confirms in part the findings of Beukes (2010) which indicated that graduates' level of employability was significantly related to their level of emotional intelligence.

Based on the findings it is recommended that a research component be included in each subject in every higher education instructional programme and curriculum. For example if the subject is taken over a three year period as is the case with a major at a traditional university that in the third year a research component must be introduced. Even though 
this is the case at traditional higher education institutions it is not the same at other higher education institutions like Universities of Technology and Further Education and Training colleges. The assimilation and presenting of information in different formats be accentuated, by having both oral and written assessment as well as presentations. The recontextualisation of information in new ways is implemented in each subject by making use of various learning modes providing a holistic view of subject matter. This could be done using case studies and or simulations. It is furthermore recommended that a generic business administration subject be included in all higher education curricula that emphasize customer service, telephone etiquette, excel training, punctuality, work ethics and financial management to address the need for transferrable employability skills and knowledge of the world of work.

In order to address the lack of soft skills as indicated by the responses of employers in the open-ended question it is recommended that a generic emotional intelligence subject be incorporated. Emotional intelligence can be defined as an array of non-cognitive abilities, capabilities, and skills that influence the individuals' capacity to succeed and cope with environmental demands and pressures (Bar-On, 2010: 57). Aspects that need to be addressed by this subject include problem-solving, stress management, conflict management and development of macro-vision skills.

\section{Conclusion}

Increasing concerns about graduate employability and the pressure on higher education to clearly demonstrate the benefits that results from the public funds it consumes has emphasize the delivery of graduates who are perceived as competent and employable within their disciplinary field. Higher education has engaged with the graduate employability debate by adjusting curricula to meet the requirements of an ever-changing employer market. The body of research on graduate employability emphases for the most part the supply side efforts of generic skills development which subsume curriculum design and delivery mechanisms. The focus of the research reported on in this article were threefold to evaluate graduates' current employability skills from the demand side, as well as to determine which demographic variable had the most influence on the before mentioned. Thirdly to elicit employers' perceptions on employability skills graduates are lacking. Both critical cross field outcomes and graduate attributes were included in the investigation - thus what graduates should know and what they should be able to do. It is the hope that in making these results explicit that it will provide a point of departure to facilitate ongoing dialogue aimed at developing higher education curricula which address the achievement of relevant transferable skills consequently increasing graduate employability.

The finding of this study are only the first step in empirically researching competencies requisite from graduates by the labour market as well as the practical implementation of the contentious matter of graduate employability. Future research endeavours might include extending the stakeholder platform to include graduates views on their employability as well as academia's understanding of graduate employability and the measurement thereof. The notion of skills might also need to be redefined within the context of the changing labour market. Differences in the perception of the private and public sector should also be investigated.

\section{References}

Backhouse, J. (2010). Importance of research driven approaches to improving undergraduate success. Paper presented at the Council on Higher Education's second colloquium on "Improving undergraduate success", March, Johannesburg, South Africa.

Bar-On, R. (2010). Emotional intelligence: an integral part of positive psychology. South African Journal of Psychology, 40(1), 54-62.

Bath, D., Smith, C., Stein, S., \& Swann, R. (2004). Beyond mapping and embedding graduate attributes: bringing together quality assurance and action learning to create a validated and living curriculum. Higher Education Research and Development, 23(3), 313-327.

Beukes, C.J. (2010). Employability and emotional intelligence of the individual within the school-to-work transition phase. Unpublished Masters' dissertation, University of South Africa, Pretoria.

Beyer, L., Wilkinson, A.C., \& Friedrich-Nel, H.S. (2010). A survey of the generic graduate skills that the Central University of Technology Radiography graduates need for the world of work. Interim, 9(1), 1-14.

Bezuidenhout, M. (2011). The development and evaluation of a measure of graduate employability in the context of the new world of work. Unpublished Masters' dissertation, University of Pretoria, Pretoria.

Bridgstock, R. (2012). The graduate attribute we've overlooked: enhancing graduate employability through career management skills. Higher Education Research and Development, 28(1), 31-44.

Campbell, A. (2010). Developing generic skills and attributes of international students: the (ir)relevance of the Australian University experience. Journal of Higher Education Policy and Management, 28(1), 31-44.

Chiappero-Martinetti, E., \& Sabadash, A. (2012). Integrating human capital and human capabilities in understanding the value of education. Paper presented at "International Research Seminar: Higher Education and Human Development", June, 
Bloemfontein, South Africa.

Cummings, J. (2010). Contextualised performance: reframing the skills debate in research education. Studies in Higher Education, 34(4), 405-419.

De Jager, H.C. (2004). Employer expectations and prospective employee realities: A model to address the need for employability skills. PhD dissertation, North-West University, Potchefstroom.

Development Policy Research Unit (DPRU). (2007). Graduate unemployment in the face of skills shortages: A labour market paradox. Cape Town: University of Cape Town.

Du Plessis, Y., \& Barkhuizen, N. (2012). Psychological capital, a requisite for organizational performance in South Africa. South African Journal of Economic and Management Sciences, 15(1), 16-30.

Du Preez, I., \& Fossey, A. (2012). Developing academic writing skills as part of graduate attributes in undergraduate curricula. South African Journal of Higher Education, 26(2), 346-357.

Gamble, N., Patrick, C., \& Peach, D. (2010). Internationalizing work-integrated learning: creating global citizens to meet the economic crisis and the skills shortages. Higher Education Research and Development, 29(5), 535-546.

Gokuladas, V.K. (2011). Predictors of employability of engineering graduates in campus recruitment drives of Indian software services companies. International Journal of Selection and Assessment, 19(3), 313-319.

Green, W., Hammer, S., \& Star, C. (2009). Facing up to the challenge: Why it is so hard to develop graduate attributes. Higher Education Research and Development, 28(1), 17-29.

Hauer, J., \& Quill, T. (2011). Educational needs assessment, development of learning objectives, and choosing a teaching approach. Journal of Palliative Medicine, 14(4), 503-508.

May, T. (2011). Social Research: Issues, methods and process (4th ed.). Berkshire: Open University Press.

McLean, M., Abbas, A., \& Ashwin, P. (2012). Pedagogic quality and inequality in undergraduate degrees. Paper presented at "International Research Seminar: Higher Education and Human Development". June, in Bloemfontein, South Africa.

McNeil, H.P., Scicluna, H.A., Grimm, M.C., Gibson, K.A., \& Jones, P.D. (2011). Successful development of generic capabilities in an undergraduate medical educational program. Higher Education Research and Development, 1-15.

Mohr, P. (2012). Understanding macro-economics. Pretoria: Van Schaik Publishers.

Mohr, P., \& Seymore, R. (2012). Understanding micro-economics. Pretoria: Van Schaik Publishers.

Nair, C.S., Patil, A., \& Mertova, P. (2009). Re-engineering graduate skills - a case study. European Journal of Engineering Education, 34(2), 131-139.

Omar, N.H., Manaf, A.A., Mohd, R.H., Kassim, A.C., Aziz, K.A. (2012). Graduates' employability skills based on current job demand through electronic advertisement. Asian Social Sciences, 8(9), 103-110.

Parker, B., \& Griesel, H. (2009). Graduate attributes: A baseline study on South African graduate from the perspective of employers. Pretoria: Higher Education South Africa \& The South African Qualification Authority.

RSA DHET (Republic of South Africa. Department of Higher Education and Training). Revised strategic plan and operational plans for the 2011/2012 financial year. http://www.dhet.gov.za/Linkclick.aspx\%fileticket=xfAHmalvQjw\%3d\&tabid=352\&mid=1174 (accessed September 29, 2012).

Salkind, N.J. (2012). Exploring research (8th ed.). Upper Saddle River, New Jersey: Pearson Education, Inc.

Selvadurai, S., Choy, E.A., \& Maros, M. (2012). Generic skills of prospective graduates from the employers' perspective. Asian Social Sciences, 8(12), 295-303.

Sharp, L. (2013). South Africa's extraordinary skills shortages - Adcorp. http://www.politicsweb.co.za/view/politicsweb/en//page 71619 ?oid=23554 (accessed March 2014).

Thompson, D., Treleaven, L., Kamvounias, P., Beem, B., \& Hill, E. (2008). Integrating graduate attributes with assessment criteria in business education: using an online assessment system. Journal of University Teaching and Learning Practice, 5(1), 34-48.

Wessels, M.L., \& Jacobs, 2010. Views of Industry and higher education on cooperative education in the Gauteng province of South Africa. Journal for New Generation Sciences, 8(3), 167-186.

Yabuuchi, S., \& Chaudhuri, S. (2009). Skills formation, capital adjustment cost and wage inequality. Review of Urban and Regional Development Studies, 21(1), 2-13. 